\title{
セミアクティブダンパの減衰特性を考慮した最適制御系設計
}

\author{
石崎 樹*1, 高橋 正樹²
}

\section{Optimal control system design considering damping characteristics of semi-active damper}

\author{
Tatsuki ISHIZAKI ${ }^{* 1}$ and Masaki TAKAHASHI ${ }^{* 2}$ \\ ${ }^{{ }^{* 1}}$ Keio Univ. Graduate School of Science and Technology \\ 3-14-1 Hiyoshi, Kohoku-ku, Yokohama 223-8522, Japan \\ ${ }^{* 2}$ Keio Univ. Department of System Design Engineering \\ 3-14-1 Hiyoshi, Kohoku-ku, Yokohama 223-8522, Japan
}

\section{Received 9 November 2014}

\begin{abstract}
To reduce the absolute acceleration and displacement of buildings during earthquakes, this paper proposes an optimal control system design method considering structural limitation of a semi-active damper. The semi-active damper incorporates a high and low switchable damping coefficient. The limitation is that the semi-active damper is able to generate control force only in the reverse direction of the velocity. In this paper, the structural passive limitation is considered by geometric relationship between the control force and damper velocity, and the area of desired control force is represented to an equation of an ellipse. By calculating the optimal control force within the limitation, an optimal control system that reduces degradation in control performance is realized. Moreover, it is possible to design the control system based on the structural characteristic and geometric configuration without parameter tuning using design seismic wave. The proposed design method is applied to the base isolated single-degree-of-freedom model with semi-active oil dampers. The control performance of the proposed method is verified through simulation using several kinds of seismic waves.
\end{abstract}

Key words : Semi-active control, Optimal control, Variable damper, Seismic isolation, Vibration control

\section{1. 緒言}

地震時の積極的な振動抑制を目的として，セミアクティブ制御を導入した建物が増加している (Kurata，et al., 1999) (吉田，2001). セミアクティブ制御は，センサからの情報に応じてダンパの特性をオンラインで切り替える ため, 小さなエネルギで効率的な振動抑制が可能であり, 能動的に加振しないためシステムとして安定である. セミアクティブ制御を実現するための装置であるダンパには，摩擦，減衰，剛性，慣性質量などの特性を可変と したものがある。このうち可変減衰ダンパは，実建物への適用事例が多く，電磁制御弁開閉により減衰係数を切 り替える可変オイルダンパや，磁気粘性流体を用いて粘度を可変とする磁気粘性ダンパが開発されている．可変 減衰ダンパ特有の問題として, 制御力を発生させることのできる方向がダンパの速度と逆方向に限定される受動 的な制約がある。そのため，この物理的制約を考慮した制御理論 (横山他，2001) や切り替え則 (栗野，2003a， 2003b) によるセミアクティブ制御の研究が進められている (Jansen and Dyke, 2000).

可変減衰ダンパを対象とした代表的なセミアクティブ制御に，最適制御理論およびその拡張型を適用した手法 がある (Dyke, et al., 1996) (吉田，藤尾，2001) (Yoshida and Dyke, 2004). 最適制御理論を用いた多くの手法では, 能動的な制御力を発生可能と仮定寸ることで最適制御理論を適用し, 最適制御力に基づいて減衰係数の切り替え を行う。しかし，最適化の過程で受動的な制約が考慮されないため，指令值となる最適制御力とダンパで発生す

\footnotetext{
No.14-00599 [DOI:10.1299/transjsme.14-00599], J-STAGE Advance Publication date : 6 February, 2015

*1 慶應義塾大学大学院 理工学研究科（下223-8522 神奈川県横浜市港北区日吉 3-14-1)

*2 正員, 慶應義塾大学 理工学部

E-mail of corresponding author: takahashi@sd.keio.ac.jp
} 
る制御力にずれが発生し，その結果として制御性能が劣化する場合がある. そのため, 評価関数の意味が曖昧と なり，受動的な制約による影響を確認しながら試行錯誤による評価関数の重みのチューニングが必要となる．ま た，設計用地震波を入力した場合の応答に基づいて評価関数の重みを選定する方法では，設計される制御系は設 計用地震波の特性に大きく依存する可能性がある．セミアクティブ制御における評価関数の重みと制御特性の関 係を定量的に示寸研究 (藤井他，2013) がなされているが，セミアクティブ制御系の体系的な設計法は未だ確立 されていない.

また近年では，制御系の制御性能をより効果的に向上させるために，構造系と制御系の双方を考慮して設計す る方法に関する研究が多数行われている. 制御系のパラメータに加えて, 構造系のパラメータも同時に設計する 場合, 全探索的な方法ではパラメータの組合せが膨大になってしまう。そのため, 制御系や構造系のパラメータ の数を減らすなどの対策や，ある指標に基づいて体系的に設計が可能な全探索的な方法に依らない制御系設計法 が必要となる，そのような方法の一例では，応答スペクトルによる最大応答の評価を用いることで, 設計用地震 波を不要と寸る一般性の向上や時刻歴応答解析にかかる計算時間の短縮が図られている (堀口, 小檜山，2012).

本研究では, セミアクティブダンパとして減衰係数が 2 段階に切り替えが可能な可変減衰ダンパを考え, ダン パの物理的特性に基づいて体系的に設計可能なセミアクティブ制御系設計法を提案することを目的とする. セミ アクティブダンパの受動的な制約に着目し,かつ, ダンパで実現可能な 2 段階の減衰係数を陽に考慮することで, 指令值となる制御力とダンパで発生する制御力のずれを低減する。これにより，提案設計法はセミアクティブダ ンパの特性に基づいて体系的に制御系を設計することができるため, 設計パラメータの試行錯誤的なチューニン グを必要とせず, また, 設計用地震波に依存しない特長を有している. 本研究では, 提案設計法による制御系が, 全探索的に重みを決定した最適制御系と同程度の制御性能であることをシミュレーションにより確認する.

\section{2. 制御系設計法}

\section{$2 \cdot 1$ 制御系設計モデル}

本研究では, 制御系の基本的な性能について論じるため, 制御系設計モデルとして 1 自由度系免震構造物モデ ルを用いる. このとき, 状態方程式は以下の式で表される.

$$
\begin{aligned}
& \dot{\boldsymbol{x}}(t)=\boldsymbol{A} \boldsymbol{x}(t)+\boldsymbol{B} u(t)+\boldsymbol{E} \ddot{z}(t) \\
& \boldsymbol{x}(t)=\left[\begin{array}{lll}
x & \dot{x}
\end{array}\right]^{T}, \quad \boldsymbol{A}=\left[\begin{array}{cc}
0 & 1 \\
-\frac{k}{m} & -\frac{c}{m}
\end{array}\right], \quad \boldsymbol{B}=\left[\begin{array}{c}
0 \\
\frac{1}{m}
\end{array}\right], \quad \boldsymbol{E}=\left[\begin{array}{c}
0 \\
-1
\end{array}\right]
\end{aligned}
$$

ただし， $\boldsymbol{x}(t)$ は状態ベクトル， $u(t)$ はセミアクティブダンパで発生する制御力, $\ddot{z}(t)$ は地動加速度を表してい る. また， $m, c, k$ はそれぞれ質量, 減衰係数, ばね定数を, $x$ は建物の地面からの相対変位を表寸.

\section{$2 \cdot 2$ セミアクティブダンパの物理的制約}

セミアクティブダンパで発生する制御力は, 受動的な減衰力である. そのため, 制御力の発生する方向には, 常にダンパの速度方向と逆である物理的制約が存在する. この物理的制約を図 1 に示す速度一制御力図において 考慮すると, 制御力が発生可能な領域は第 2, 4 象限, 制御力が発生不可能な領域は第 1,3 象限で表される. さ らに, ダンパの減衰係数の切り替えが連続的でなく 2 段階の $c_{h}, c_{l}$ の場合, 制御力の発生可能な領域は減衰係数 を傾きとする 2 直線上に限定される.ここで， $c_{h}, c_{l}$ はセミアクティブダンパ系の合計の減衰係数を表しており， 複数本のセミアクティブダンパから構成される場合には, 全てのダンパの減衰係数が同時に切り替わることを想 定している，従来の制御系設計法では，速度一制御力図において制御力が発生できない領域を考慮せずに，全域 において能動的な制御力を発生可能と仮定しており, 減衰係数の切り替え時に指令值と発生する制御力にずれが 生じる原因となっている. 本研究では, ダンパの物理的制約を速度一制御力図で考慮した制御系を設計すること で，体系的な制御系設計法の構築を目指す. 


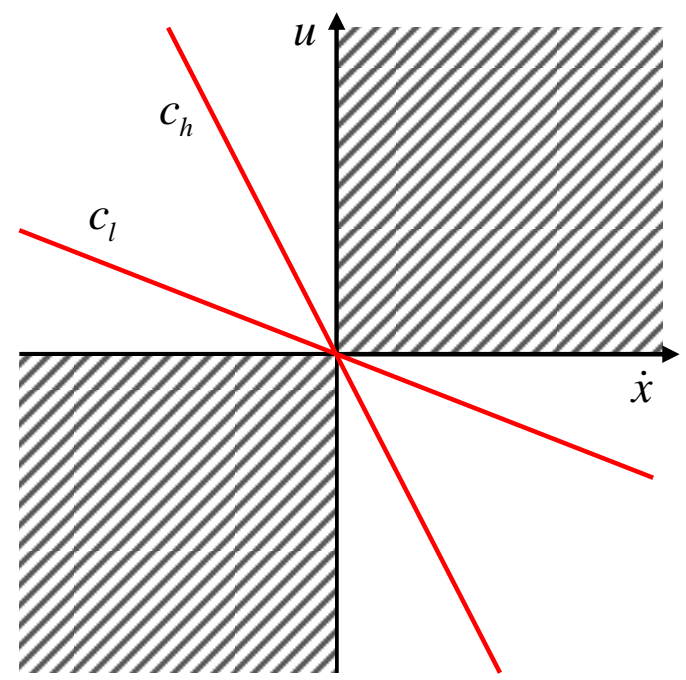

Fig. 1 Relationship between velocity and damping force

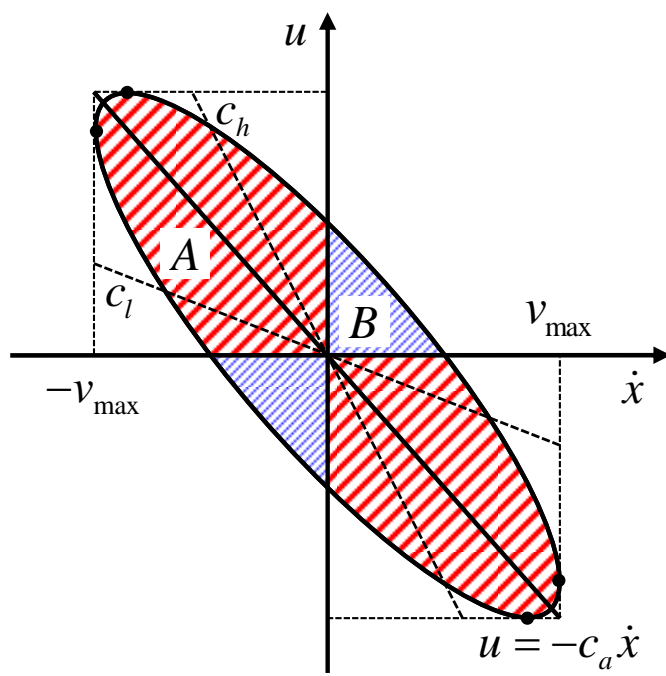

Fig. 2 Design concept of feedback gain

\section{$2 \cdot 3$ フィードバックゲインの導出}

ダンパの物理パラメータから指令值となる所望の制御力が分布する領域を決定し, 領域内に制御力を発生させ るフィードバックゲインを導出する。本研究では, 所望の制御力が分布する領域を, 図 2 に示すような棈円とし て設定する.

はじめに，所望の制御力が発生する楕円の傾きと長軸，短軸を決定する．一般に，セミアクティブダンパでは 減衰係数の切り替えが適度に発生することで制御性能が向上する. そこで，指令值となる制御力の領域がダンパ の減衰係数 $c_{h}, c_{l}$ で表される 2 直線の両方に重なるように, 長軸の傾きの絶対值 $c_{a}$ を $c_{h}, c_{l}$ の中間值に設定する. また，楕円の長軸，短軸を，ダンパの最大速度 $v_{\max }$ に基づいて設定する. ダンパの最大速度は，外乱である地震 波の大きさに依存するため上限值として厳密に設定することは困難であるが，想定可能な值である．速度一制御 力図において, 長軸の傾き $-c_{a}$, 速度の定義域 $-v_{\max } \leq \dot{x} \leq v_{\max }$ を満たす楕円の方程式は, 係数 $\beta$ の関数として以 下の式で表される.

$$
\begin{aligned}
& u(\beta)=-\sqrt{c_{a}^{2}-\beta^{2}} \dot{x} \pm \beta \sqrt{v_{\max }^{2}-\dot{x}^{2}} \\
& c_{a}=\frac{c_{h}+c_{l}}{2}
\end{aligned}
$$

さらに条件を加えて, 式（3）で表される楕円の中から最も適当な棈円を選択し， $\beta$ の值を一意に決定する. 制御性能が向上するためには，制御力が発生する棈円の領域は，制御力が発生可能な第 2, 4 象限を中心に多く分 布し，かつ，制御力が発生不可能な第 $1 ， 3$ 象限には少なく分布することが望ましい。 これは，第 $1 ， 3$ 象限に算 出された制御力は, ダンパでは発生できない方向の制御力であるため, 必ず制御力に大きなずれが生じるからで ある. そこで，セミアクティブダンパの受動的な制約を考慮する評価関数を設定し，楕円の方程式を一意に決定 する. 図 2 において, 第 2, 4 象限にある棈円内部の面積を $S_{A}$, 第 1,3 象限にある棈円内部の面積を $S_{B}$ とし, 評価関数 $S$ を以下の式で設定する.

$$
S\left(\beta_{\mathrm{opt}}\right)=\max _{\beta}\left\{S_{A}-S_{B}\right\}
$$

$S$ は制御力が発生可能な領域と発生不可能な領域の差を表し，最大化することが望ましいため，Sが最大とな る $\beta$ を $\beta_{\mathrm{opt}}$ として決定する. 式（3）に式（5）で選択した $\beta_{\mathrm{opt}}$ を代入すると，セミアクティブダンパの物理的制 約を考慮した楕円の方程式は以下の式で一意に決定される. 


$$
u_{d}=-\sqrt{c_{a}^{2}-\beta_{\mathrm{opt}}{ }^{2}} \dot{x} \pm \beta_{\mathrm{opt}} \sqrt{v_{\max }^{2}-\dot{x}^{2}}
$$

これにより，制御力のずれを減少させることを考慮した制御力 $u_{d}$ を算出する制御系がセミアクティブダンパの 物理パラメータのみから設計可能となる.

次に, 式（6）で表される所望の制御力の領域を表寸楕円の方程式を，変位と速度のフィードバック制御系に帰 着させる.フィードバックゲインを $\boldsymbol{F}=\left[\begin{array}{ll}k_{0} & c_{0}\end{array}\right]$ とすると，制御力は以下の式で表される.

$$
u_{d}=-\boldsymbol{F} \boldsymbol{x}=-c_{0} \dot{x}-k_{0} x
$$

ここで, 変位と速度の関係を用いて式（7）から変位の項を消去し，速度一制御力図における領域として表現す ることを考える. 1 自由度系の運動を外力の加わらない自由振動とすると, 初期条件を $x(0)=0, \dot{x}(0)=v_{\max }$ とし て, 変位と速度の関係は固有振動数 $\omega_{n}=\sqrt{k / m}$ を用いて以下の式で表される.

$$
x^{2}+\left(\frac{\dot{x}}{\omega_{n}}\right)^{2} \leq\left(\frac{v_{\max }}{\omega_{n}}\right)^{2}
$$

ここで，等号成立は非減衰自由振動の場合で，減衰自由振動の場合は位相平面上を滑らかに原点に向かって収束 する軌跡を描く、フィードバックゲインによる制御力の発生する領域の境界の方程式を求めるため, 式 (8) の等 号成立の関係を式（7）に代入すると，制御力は以下の式で表される.

$$
u_{d}=-c_{0} \dot{x} \pm \sqrt{\frac{m}{k} k_{0}^{2} v_{\max }^{2}-\frac{m}{k} k_{0}^{2} \dot{x}^{2}}
$$

セミアクティブダンパの物理的制約を考慮した式（6）と，フィードバックゲインによる式 (9) を係数比較し て $k_{0}, \quad c_{0}$ を求めることで, フィードバックゲインは以下の式で与えられる.

$$
\boldsymbol{F}=\left[\begin{array}{ll}
\beta_{\mathrm{opt}} \sqrt{\frac{k}{m}} & \sqrt{c_{a}^{2}-\beta_{\mathrm{opt}}^{2}}
\end{array}\right]
$$

以上より，セミアクティブダンパの物理的制約を速度一制御力図から考慮することで，制御系のフィードバッ クゲインを設計した.

\section{$2 \cdot 4$ 最適制御系設計による安定性の保証}

セミアクティブ制御系は受動的であり, 安定なシステムである. そのため, 指令值に依らず安定性は保証され るが, 実際には理論的な安定性が保証された制御力に基づいた指令值を入力する方が望ましいと考える. そこで, 本提案設計法により導出した制御力が最適制御理論に基づく制御系設計法でも導出可能であることを確認する.

変位と速度, 制御力から構成される評価関数を式（11）に示す.

$$
\begin{aligned}
& J=\int_{0}^{\infty}\left(k_{j} x^{2}+c_{j} \dot{x}^{2}+u^{2}\right) d t=\int_{0}^{\infty}\left(\boldsymbol{x}^{T} \boldsymbol{Q x}+R u^{2}\right) d t \\
& \boldsymbol{Q}=\left[\begin{array}{cc}
k_{j} & 0 \\
0 & c_{j}
\end{array}\right], \quad R=1
\end{aligned}
$$

評価関数を最小にする最適フィードバックゲインは, 次式で与えられる.

$$
\boldsymbol{F}=R^{-1} \boldsymbol{B}^{T} \boldsymbol{P}
$$


ただし，Pは以下のリカッチ方程式の一意正定解である.

$$
\boldsymbol{P A}+\boldsymbol{A}^{T} \boldsymbol{P}-\boldsymbol{P B} R^{-1} \boldsymbol{B}^{T} \boldsymbol{P}+\boldsymbol{Q}=\mathbf{0}
$$

ここで，式（13），(14）に $\boldsymbol{A}, \boldsymbol{B}, \boldsymbol{Q}, R$ をそれぞれ代入すると，最適フィードバックゲイン $\boldsymbol{F}$ は以下のように表 される.

$$
\boldsymbol{F}=\left[\begin{array}{lll}
-k+\sqrt{k^{2}+k_{j}} & -c+\sqrt{2 m \sqrt{k^{2}+k_{j}}-2 m k+c^{2}+c_{j}}
\end{array}\right]
$$

提案設計法で導出した $\boldsymbol{F}=\left[\begin{array}{ll}k_{0} & c_{0}\end{array}\right]$ と式 (15) を比較することにより, 式 (11) に示寸評価関数の重み係数 $k_{j}$, $c_{j}$ をそれぞれ式（16）に示すように設定することで，提案制御系により導出したフィードバック制御系は最適制 御理論に基づいた最適フィードバック制御系と等価となることが確認される.

$$
\begin{aligned}
& k_{j}=k_{0}^{2}+2 k k_{0} \\
& c_{j}=c_{0}^{2}+2 c c_{0}-2 m k_{0}
\end{aligned}
$$

\section{3. シミュレーション}

\section{$3 \cdot 1$ シミュレーションモデル}

本研究では, シミュレーションモデルとして免震層のセミアクティブオイルダンパを Maxwell モデルとしてモ デル化した 1 自由度系免震構造物モデルを用いる. Maxwell モデルは, 動特性を考慮し, ダッシュポットとばね を直列に結合したモデルである. 図 3 にモデル, 表 1 に諸定数を示寸.

このとき, 状態方程式は以下の非線形システムとして表される.

$$
\begin{aligned}
& \dot{\boldsymbol{x}}_{m}(t)=\boldsymbol{A}_{m} \boldsymbol{x}_{m}(t)+\boldsymbol{B}_{m}\left\{x(t)-x_{s}(t)\right\} u_{m}(t)+\boldsymbol{E}_{m} \ddot{z}(t), \quad \boldsymbol{y}_{m}(t)=\boldsymbol{C}_{m} \boldsymbol{x}_{m}(t) \\
& \boldsymbol{x}_{m}(t)=\left[\begin{array}{lll}
x_{s} & x & \dot{x}
\end{array}\right]^{T}, \quad \boldsymbol{A}_{m}=\left[\begin{array}{ccc}
0 & 0 & 0 \\
0 & 0 & 1 \\
\frac{k_{s}}{m} & -\frac{k_{s}+k}{m} & -\frac{c}{m}
\end{array}\right] \boldsymbol{B}_{m}=\left[\begin{array}{c}
k_{s} \\
0 \\
0
\end{array}\right], \quad \boldsymbol{C}_{m}=\left[\begin{array}{lll}
0 & 1 & 0 \\
0 & 0 & 1
\end{array}\right], \quad \boldsymbol{E}_{m}=\left[\begin{array}{c}
0 \\
0 \\
-1
\end{array}\right]
\end{aligned}
$$

$$
u_{m}(t)=c_{s}^{-1}(t)
$$

ただし， $\boldsymbol{x}_{m}(t)$ は状態ベクトル， $c_{s}(t)$ は可変粘性減衰， $\ddot{z}(t)$ は地動加速度を表している.

想定している可変減衰ダンパは, 弁の開閉を調整して減衰係数を高減衰係数 $c_{h}^{1}$ と低減衰係数 $c_{l}^{1}$ の 2 段階に切り 替え可能なオイルダンパである.オイルダンパ 1 台当たりの減衰係数はそれぞれ $c_{h}^{1}$ を $1.47 \times 10^{7} \mathrm{Ns} / \mathrm{m} ， c_{l}^{1}$ を $8.30 \times 10^{5} \mathrm{Ns} / \mathrm{m}$ とした. オイルダンパ 1 台当たりの Maxwell モデルのばね剛性 $k_{s}^{1}$ を $2.94 \times 10^{7} \mathrm{~N} / \mathrm{m}$ とした. また, 減衰係数を切り替える際に時間遅れが生じるため, 指令值に対するダンパの応答の遅れを次式に示す 1 次遅れ要 素でモデル化した (福喜多, 高橋, 2011).

$$
G(s)=\frac{1}{T s+1}
$$

ただし，時定数 $T$ は $30 \mathrm{~ms}$ とした．以上の特性を持つセミアクティブダンパを免震層に 4 台設置した. 4 台分 に相当する各パラメータは， $c_{h}=4 c_{h}^{1}=5.88 \times 10^{7} \mathrm{Ns} / \mathrm{m}, \quad c_{l}=4 c_{l}^{1}=3.32 \times 10^{6} \mathrm{Ns} / \mathrm{m}, \quad k_{s}=4 k_{s}^{1}=1.18 \times 10^{8} \mathrm{~N} / \mathrm{m}$ であ る. 


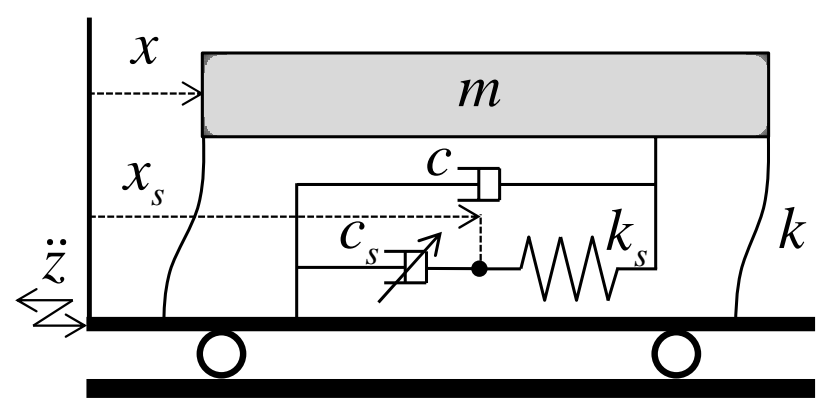

Table 1 Specification of the single-degree-of-freedom model

Fig. 3 Single-degree-of-freedom model

\section{$3 \cdot 2$ 制御系設計}

制御系設計に必要なパラメータは, ダンパの物理的特性である $c_{h}, c_{l}, v_{\max }$ と図形的な条件から定まる $\beta_{o p t}$ お よび構造物の固有振動数である. 減衰係数 $c_{h}, c_{l}$ は設置するダンパの特性に依存する. また, 最大速度 $v_{\text {max }}$ は建 築物の耐震設計に用いられる「極めて稀であるが非常に強い地震動」であるレベル 2 の地震動を想定し， $v_{\text {max }}=50 \mathrm{~cm} / \mathrm{s}$ と寸る. セミアクティブダンパの物理的制約を考慮した楕円の方程式に， $c_{h}, c_{l}, v_{\text {max }}$ の值を代入 して $\beta$ の関数を作成し， $\beta$ を $8.0 \times 10^{6}$ から $2.8 \times 10^{7}$ まで $4.0 \times 10^{6}$ 刻みで変化させたときの速度一制御力図におけ る楕円の形状変化を図 4 に示す。 また, 図 5 に楕円内部の面積 $S_{A}, S_{B}$ および評価関数 $S$ の值を示す.

図 4 より， $\beta$ を変化させることで設計意図通りに傾きと最大值が一定の楕円が連続して描かれていることが確 認できる.これらの楕円を描く $\beta$ のうち, 図 5 より, 評価関数 $S$ が最大となる $\beta$ の值として $\beta_{\mathrm{opt}}=2.0 \times 10^{7}$ を制 御系設計に用いる. 以上より, 式 $(10)$ に $c_{h}, c_{l}, v_{\max }$ および $\beta_{\mathrm{opt}}$ の值を代入することで, 最適フィードバック ゲインを作成した.

以下の手順に沿ってセミアクティブダンパの減衰係数の切り替えを行う.

1) 指令值となる制御力 $u_{d}$ の算出

$$
u_{d}=-\boldsymbol{F} \boldsymbol{y}_{m}
$$

2) 指令值となる減衰係数 $c_{d}$ の算出

$$
c_{d}=-\frac{u_{d}}{\dot{x}-\dot{x}_{s}}
$$

3) セミアクティブダンパの減衰係数 $c_{s}$ の切り替え

$$
c_{s}=\left\{\begin{array}{ll}
c_{h} & \left(c_{d}>c_{t h}\right) \\
c_{l} & \left(c_{d}<c_{t h}\right)
\end{array}, \quad c_{t h}=\frac{c_{h}+c_{l}}{2}\right.
$$

\section{$3 \cdot 3$ シミュレーション条件}

El Centro 1940 NS，Taft 1952 EW，Hachinohe 1968 NS の各地震波に対してシミュレーションを行い，制御性能 を検討した．地震波の記録は最大速度が $50 \mathrm{~cm} / \mathrm{s}$ （Level 2）になるようにスケーリングを行った. サンプリング周 期は $10 \mathrm{~ms}$ とした.

パッシブ制御の制御性能を確認するため，減衰係数が高減衰係数 $c_{h}$ で一定の場合（Passive high）と低減衰係数 $c_{l}$ で一定の場合（Passive low）についてシミュレーションを行った. 


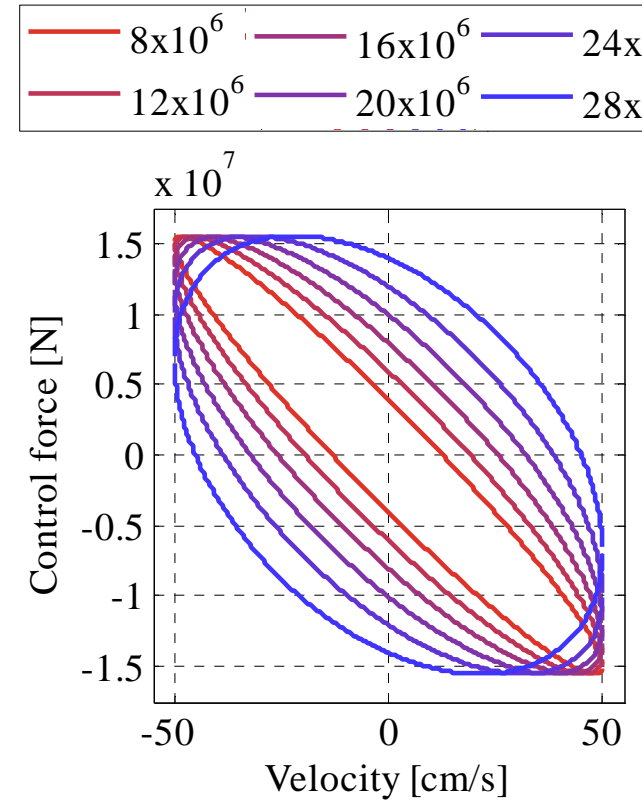

Fig. 4 Ellipse shape change due to $\beta$

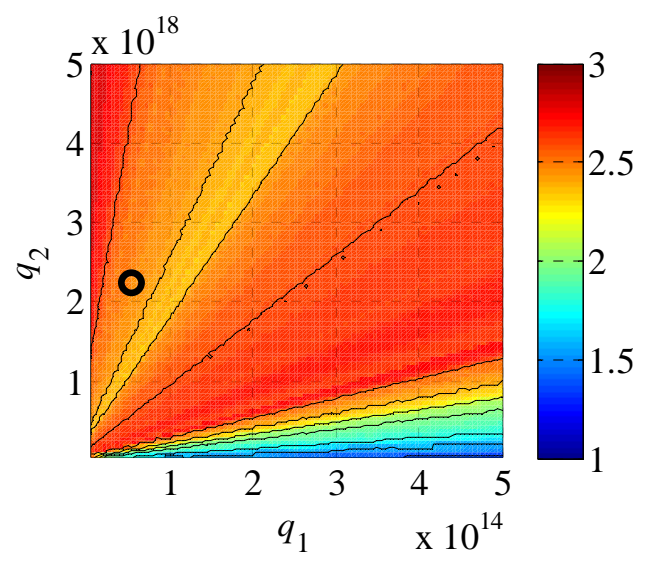

Fig. 6 Normalized acceleration contour map

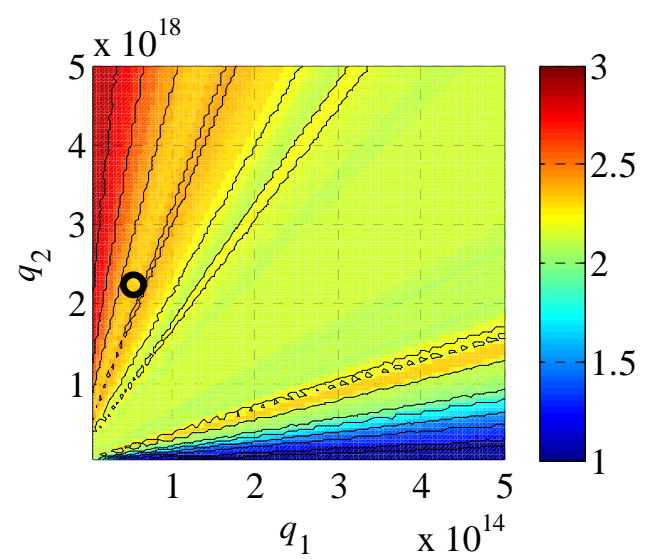

Fig. 8 Normalized control force contour map

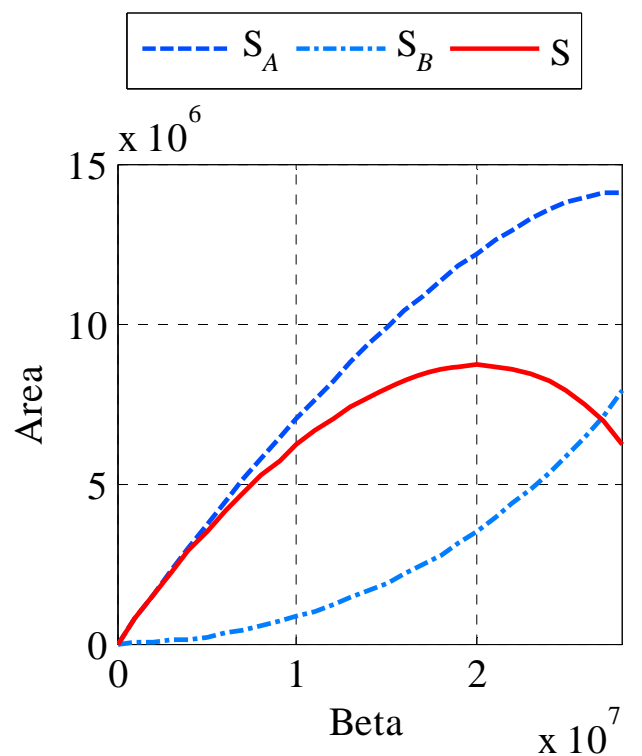

Fig. 5 S value change due to $\beta$

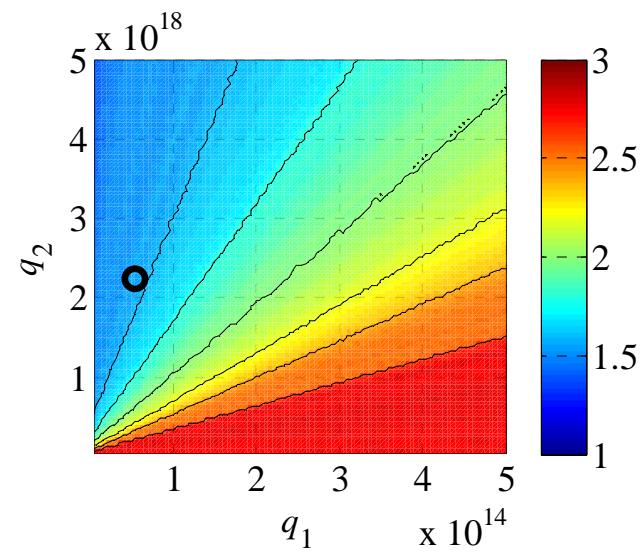

Fig. 7 Normalized displacement contour map

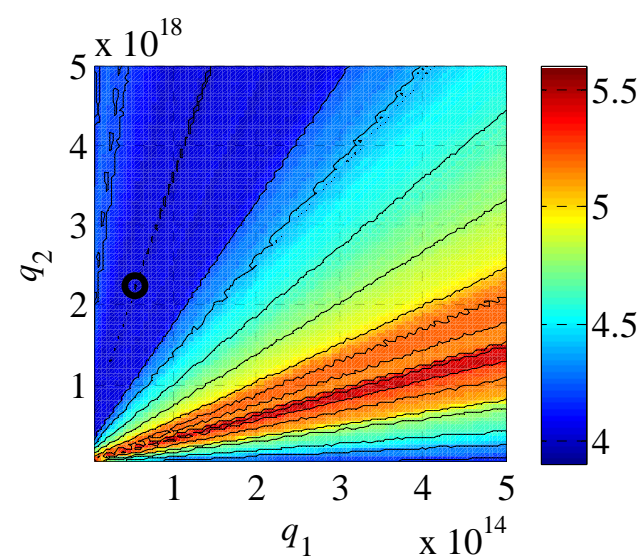

Fig. 9 Sum of normalized acceleration and displacement

また，提案手法の制御性能を確認するため，比較手法として式（24）に示寸変位と絶対加速度, 制御力から構 成される評価関数に基づく最適制御系を設計した.

$$
J_{c}=\int_{0}^{\infty}\left(q_{1}(\ddot{x}+\ddot{z})^{2}+q_{2} x^{2}+u^{2}\right) d t
$$


評価関数の重み $q_{1} ， q_{2}$ を決定するため， $q_{1}$ を $5.00 \times 10^{12}$ から $5.00 \times 10^{14}$ まで $5.00 \times 10^{12}$ 刻みで 100 通り， $q_{2}$ を $5.00 \times 10^{16}$ から $5.00 \times 10^{18}$ まで $5.00 \times 10^{16}$ 刻みで 100 通りの合計 $100 \times 100=10000$ 通りの組み合わせで, 3 種類の地 震波に対してシミュレーションを行った. 各地震波について, それぞれの重みの組み合わせにおける最大加速度,

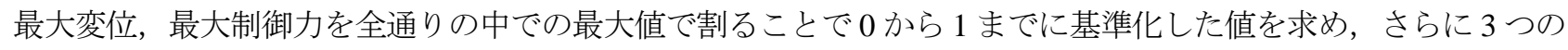
地震波の結果を足し合わせたコンター図を図 6 から図 8 に示す.また, 図 9 に図 6 と図 7 を重ね合わせた図を示 す. 図 9 に示寸結果より基準化した最大加速度と最大変位の合計が最小となる重みの組み合わせとして, 評価関 数の重みを $q_{1}=5.50 \times 10^{13}, q_{2}=2.25 \times 10^{18}$ と選択した.

\section{$3 \cdot 4$ シミュレーション結果}

各地震波に対する最大応答の結果を図 10 から図 12 に示す. El Centro, Taft, Hachinohe の各地震波に対して, 提案手法が比較手法のチューニングした最適制御系と同等，あるいは，ある程度の劣化の範囲内の性能を有する ことがわかる. また，パッシブ制御と比較して加速度応答，変位応答ともにセミアクティブ制御として妥当な性 能が出ているといえる.

入力地震波を Hachinohe とした場合の速度一制御力図を図 13,14 に示寸. 比較手法では, 制御力とダンパで発 生している制御力に大きな差が生じている. 一方, 提案手法では, 制御力の領域が設計意図通り 2 段階の減衰係 数の切り替えが発生するように分布していることが確認できる. また, 提案手法が比較手法に比べて制御力が発 生できない第 $1 ， 3$ 象限における制御力が少なく, 制御系設計時に想定した制御力と減衰係数の切り替えにより発 生している制御力との差が少ないことがわかる.

また，時刻歷応答を図 15 に示寸，制御力の時刻歴応答より，提案手法と比較手法では，指令值となる制御力 $u_{d}$ は, 符号は等しいが絶対值が大きく異なることが確認できる. そのため, 図 13，14で確認したように提案手法の 方が制御力の差が少ないことがわかる. ただし, 減衰係数の切り替えの時刻歴応答に着目すると, 提案手法と比 較手法では指令となる制御力が大きく異なるにも関わらず，切り替えのタイミングはほぼ同じタイミングとなっ ている. したがって, 提案手法と比較手法では, 制御性能がほぼ等しい結果となっていることが確認できる.

本結果より，最適制御理論に基づいて試行錯誤的にコンター図から評価関数の重み付けを決定した最適フィー ドバック制御系とほぼ同等の制御性能を有する制御系が，提案設計法により導出可能であることを確認した。

\section{4. 結 言}

1 質点免震構造物に対して, 2 段階に切り替え可能な可変減衰ダンパの受動的な制約を考慮したセミアクティブ 制御系設計法を提案した. 提案設計法はセミアクティブダンパの物理的特性と構造物の固有振動数から設計可能 であり，設計用地震波による試行錯誤的なチューニングが不要な体系的な制御系設計法である．提案設計法では ダンパの速度と制御力の関係に着目し，セミアクティブダンパの物理的制約を楕円の図形条件に帰着させること で，セミアクティブ制御系のフィードバックゲインの設計を可能とした．提案設計法を用いることで，セミアク ティブダンパにおける指令值と発生する制御力の差が減少するため, 最適制御系の評価関数の設計意図に近い制 御が可能となる. 提案設計法では設計時に地震動による応答解析を行っていないが, 応答解析を行いチューニン グした最適制御系とほぼ同等の制御性能が得られることを, 数值シミュレーションにより確認した.

本研究ではセミアクティブダンパの減衰係数を事前に想定したが, 提案設計法はダンパの物理的特性から一意 に制御系を設計できるため, 構造系と制御系の双方を考慮した設計において構造系のパラメータのみに帰着した セミアクティブ免震システムの制御系設計として拡張可能である. 今後の課題は, 多質点系への適用と Maxwell モデルの動特性を考慮した制御系設計への拡張である. 

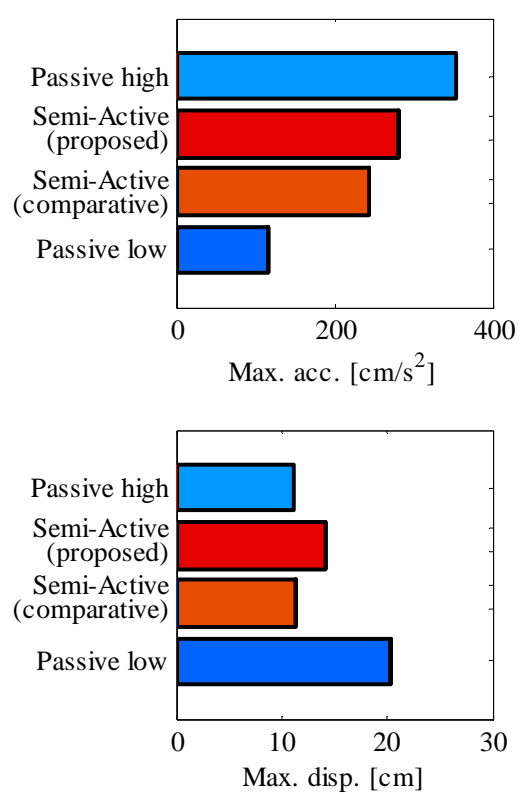

Fig. 10 Maximum response (El Centro)
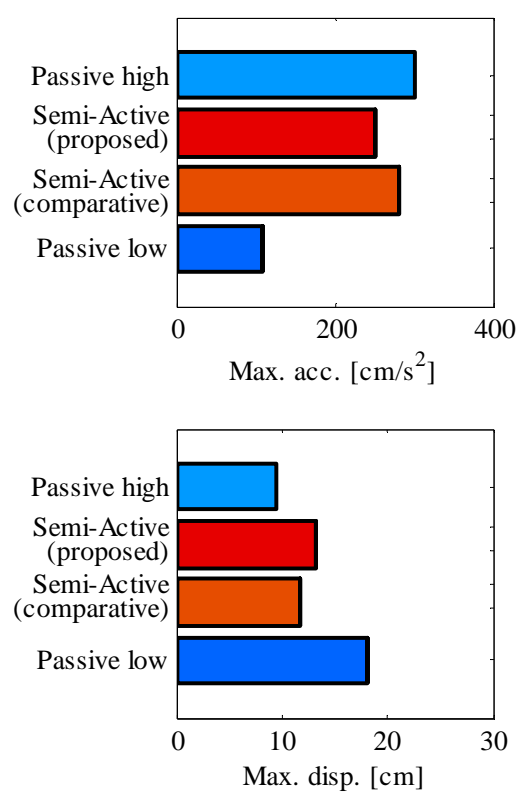

Fig. 11 Maximum response (Taft)
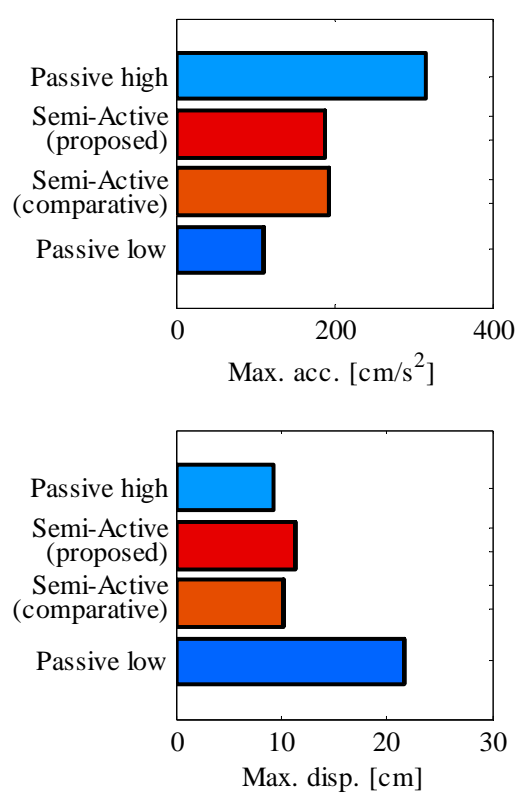

Fig. 12 Maximum response (Hachinohe)

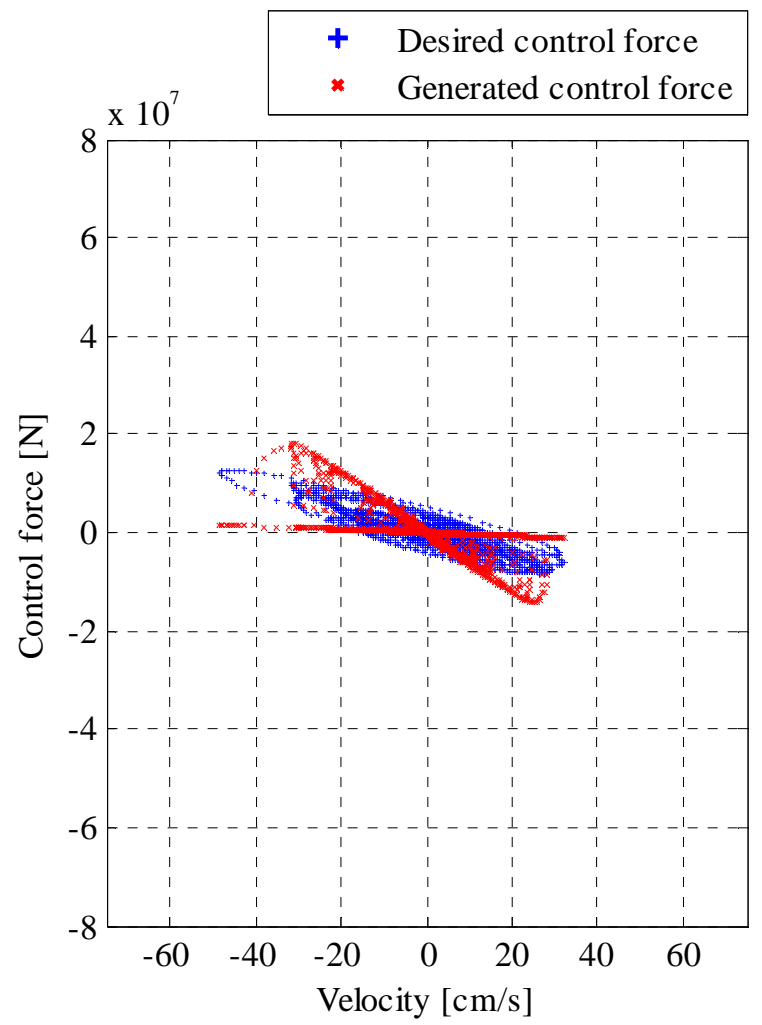

Fig. 13 Relationship between velocity and force of proposed design method (Hachinohe). Desired control force is plotted in the shape of an ellipse as designed.

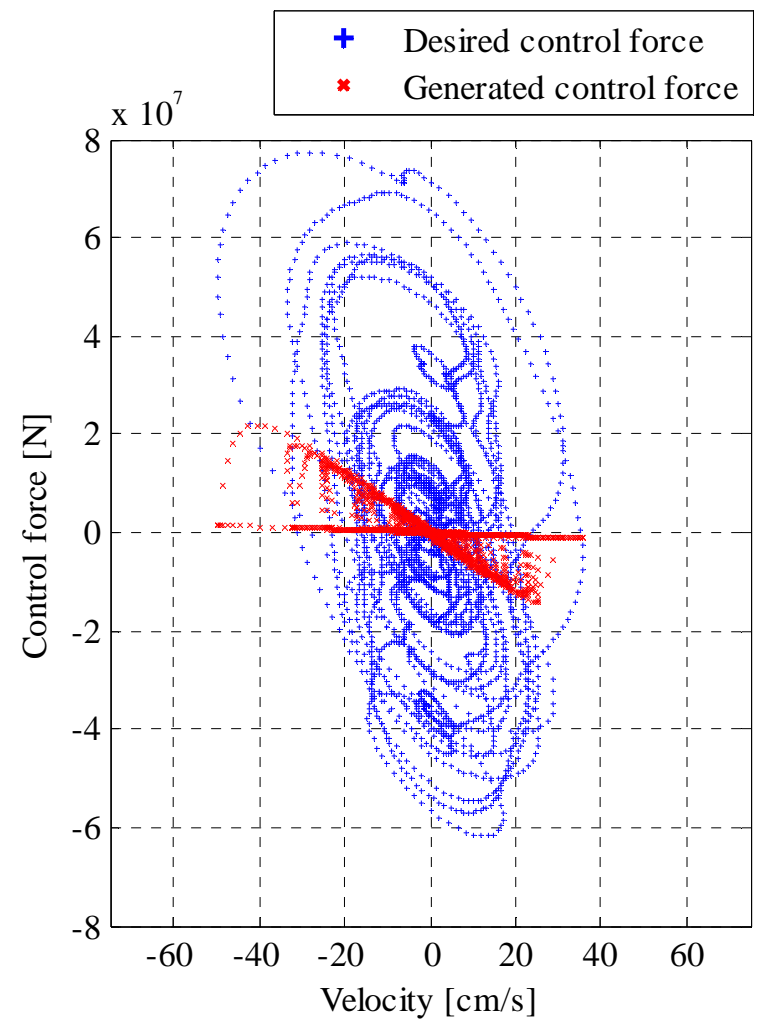

Fig. 14 Relationship between velocity and force of comparative method (Hachinohe). Desired control force is plotted widely in all quadrants. 

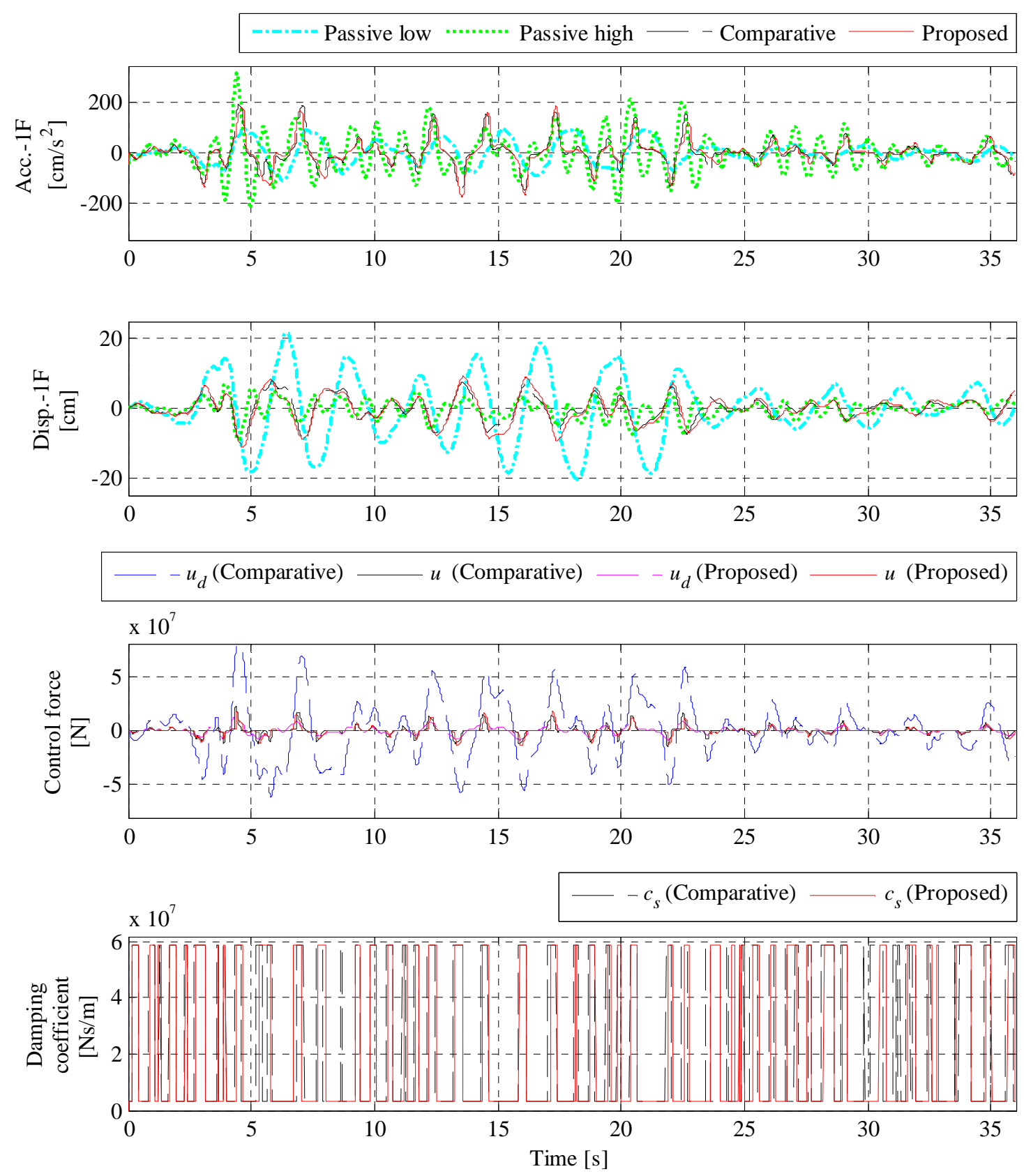

Fig. 15 Time history response (Hachinohe)

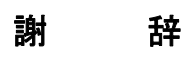

本研究は JSPS 科研費 24360230 の助成を受けたものである.

文献

Dyke, S. J., Spencer Jr, B. F., Sain, M. K. and Carlson, J. D., Modeling and control of magnetorheological dampers for seismic response reduction, Smart Materials and Structures, Vol. 5, No. 5 (1996), pp. 565-575.

藤井嵩広, 藤谷秀雄, 向井洋一, MR ダンパーの最適制御によるセミアクティブ制御効果の評価 - システム特性評 価とパラメータ設定法 - , 日本建築学会構造系論文集, Vol. 78, No. 689 (2013), pp. 1237-1245.

福喜多輝, 高橋正樹, 長周期地震動を受ける免震構造物の応答評価に基づくセミアクティブ制御, 日本機械学会 
論文集 C 編, Vol.77, No.777 (2011), pp.1649-1660.

堀口知宏，小檜山雅之，性能設計を目的とした線形二次レギュレータで制御される一質点系建物の構造系・制御系 の同時最適化，日本建築学会構造系論文集, Vol.77, No.675 (2012), pp.715-722.

Jansen, L. M. and Dyke, S. J., Semiactive control strategies for MR dampers: A comparative study, Journal of Engineering Mechanics, Vol. 126, No. 8 (2000), pp. 795-803.

Kurata, N., Kobori, T., Takahashi, M., Niwa, N. and Midorikawa, H., Actual seismic response controlled building with semi-active damper system, Earthquake Engineering and Structural Dynamics, Vol. 28 (1999), pp. 1427-1447.

栗野治彦, Maxwell 型セミアクティブダンパの振動制御性能に関する基礎的考察，日本建築学会構造系論文集， No.564 (2003a), pp.63-70.

栗野治彦, ON/OFF 型セミアクティブダンパの分散型制御手法に関する研究, 日本建築学会構造系論文集, No.571 (2003b), pp.79-86.

横山誠, Hedrick, J. K., 外山茂浩, セミアクティブサスペンションのスライディングモード制御, 日本機械学会論 文集 C 編, Vol.67, No.657 (2001), pp.1449-1454.

吉田和夫，世界初のセミアクティブ免震ビル，日本機械学会誌, Vol.104, No.995 (2001), pp.698-702.

吉田和夫, 藤尾忠洋, 双線形最適制御理論とセミアクティブ免震制御への応用，日本機械学会論文集 C 編, Vol.67, No.656 (2001), pp.992-998.

Yoshida, O. and Dyke, S. J., Seismic control of a nonlinear benchmark building using smart dampers, Journal of Engineering Mechanics, Vol. 130, No. 4 (2004), pp. 386-392.

\section{References}

Dyke, S. J., Spencer Jr, B. F., Sain, M. K. and Carlson, J. D., Modeling and control of magnetorheological dampers for seismic response reduction, Smart Materials and Structures, Vol. 5, No. 5 (1996), pp. 565-575.

Fujii, T., Fujitani, H. and Mukai, Y., Performance evaluation of semi-active optimal control system by MR damper: Evaluation of system properties of semi-active optimal control system and control parameter determination, Journal of Structural and Construction Engineering, Vol. 78, No. 689 (2013), pp. 1237-1245 (in Japanese).

Fukukita, A. and Takahashi, M., Semi-active control for base isolated structure using response evaluator subjected to long-period earthquake ground motion, Transactions of the Japan Society of Mechanical Engineers, Series C, Vol.77, No.777 (2011), pp.1649-1660 (in Japanese).

Horiguchi, C. and Kohiyama, M., Simultaneous optimization of structural and control systems of a SDOF building with a linear quadratic regulator controller aiming at performance-based design, Journal of Structural and Construction Engineering, Vol.77, No.675 (2012), pp.715-722.

Jansen, L. M. and Dyke, S. J., Semiactive control strategies for MR dampers: A comparative study, Journal of Engineering Mechanics, Vol. 126, No. 8 (2000), pp. 795-803.

Kurata, N., Kobori, T., Takahashi, M., Niwa, N. and Midorikawa, H., Actual seismic response controlled building with semi-active damper system, Earthquake Engineering and Structural Dynamics, Vol. 28 (1999), pp. 1427-1447.

Kurino, H., Fundamental study of structural control capacity of Maxwell type semi-active damper, Journal of Structural and Construction Engineering, No. 564 (2003a), pp. 63-70 (in Japanese).

Kurino, H., A study on decentralized structural control algorithm for ON/OFF type semi-active dampers, Journal of Structural and Construction Engineering, No. 571 (2003b), pp. 79-86 (in Japanese).

Yokoyama, M., Hedrick, J. K. and Toyama, S., A sliding mode controller for semi-active suspension systems, Transactions of the Japan Society of Mechanical Engineers, Series C, Vol. 67, No. 657 (2001), pp. 1449-1454 (in Japanese).

Yoshida, K., First building with semi-active base isolation, The Japan Society of Mechanical Engineers, Vol.104, No.995 (2001), pp.698-702 (in Japanese).

Yoshida, K. and Fujio, T., Bilinear optimal control theory and its application to semi-active vibration isolation control, Transactions of the Japan Society of Mechanical Engineers, Series C, Vol. 67, No. 656 (2001), pp. $992-998$ (in Japanese).

Yoshida, O. and Dyke, S. J., Seismic control of a nonlinear benchmark building using smart dampers, Journal of Engineering Mechanics, Vol. 130, No. 4 (2004), pp. 386-392. 